\title{
Measuring the application of information literacy skills after completion of a Certificate in Information Literacy
}

\author{
Janine Lockhart ${ }^{1}$ \\ lockhartj@cput.ac.za \\ ORCID: orcid.org/0000-0002-5176-6423
}

\begin{abstract}
Received: 30 November 2015
Accepted: 15 January 2016

The current assessment method used by the Cape Peninsula University of Technology Libraries for the summative assessment of the short course, Certificate in Information Literacy (CIL), is by multiplechoice questions through the Learning Management System, Blackboard. Students also complete a pre-essay and pre-test before the training intervention and a post-essay and post-test thereafter. This research reports on how students applied their newly-taught Information Literacy (IL) skills when writing a subject-specific essay (post-essay) and how that related to their scores in the pre-essay/test and post-test. The sample of forty-two students consisted of two groups of first-year students from a single class. In this study it has been confirmed that offering a short course in IL, such as the CIL, improved the information literacy skills of students. It showed improvement in the knowledge gained by students in the multiple-choice assessment as well as the application of IL skills in their essay assignments.
\end{abstract}

Keywords: Information Literacy, assessment, academic libraries, Cape Peninsula University of Technology

\section{Introduction and problem statement}

Much has been done to integrate Information Literacy (IL) into the curriculum at the Cape Peninsula University of Technology (CPUT), a university in Cape Town, South Africa, offering certificates, diplomas and degrees across its six faculties (Applied Sciences, Business and Management Sciences, Education, Engineering, Health and Wellness Sciences and Informatics and Design): an institutional Information Literacy (IL) policy was approved in 2009; a university Information Literacy Committee (ILC) was formed to oversee and monitor all information literacy activities at CPUT; an IL curriculum was developed; a short course called Certificate of Information Literacy (CIL) was registered; and the teaching skills of librarians are continually being developed. To further contribute to IL at the university, librarians felt that they needed to focus on the assessment of IL skills, the assessment methods and a continuous evaluation of the validity and reliability of the IL assessment instruments being used. It is important for academic libraries to show the value being added and the contribution they are making to the development of students. The current assessment method used by CPUT Libraries for the summative assessment of the short course $(\mathrm{CIL})$ is by multiple-choice questions through the Learning Management System (LMS), Blackboard. In addition, as requested by the researcher, the CIL is taught with a subject-specific essay assignment so that students understand how to apply what they have learned, therefore adding more value to the academic programme.

The CIL short course was registered at the end of 2012 by CPUT Libraries at CPUT's short course department, the Centre for Professional and Personal Development. The short course was offered to mostly first-year and Extended Curriculum Programme (ECP) students from 2013 by arrangement between the lecturer and their librarian. The ECP is for students who require extra support and more time to complete their qualifications: first-year subjects are offered over two years (Cape Peninsula University of Technology 2015). The CIL offers five modules over five weeks and students complete an online IL multiple-choice assessment which they access via the LMS. The assessment consists of 100 multiple-choice questions of which students receive a random selection of 50 to complete in one hour. Students who pass the assessment receive a formal CPUT short course certificate (Lockhart 2015). The assessment is an open-book test and students are allowed to consult their notes and hand-outs. It is hoped that further learning could take place while students do the test.

During 2014, the first part of this study was completed. It was to evaluate the validity and reliability of the existing online information literacy skills assessment instrument being used at the CPUT Libraries to assess the CIL (Lockhart 2014). Item analysis was done on assessment data of students who were tested during 2013. According to Nunnally (1972: 186) the item analysis test will indicate "which items should be chosen for new tests and which items need to be either revised or discarded". The item analysis study highlighted "weaknesses and problematic areas in the test" as it looked at each of the questions which was then "re-evaluated, adjusted or even discarded in some cases" to improve the assessment instrument (Lockhart 2014: 41). Twenty-three questions were replaced, eighteen images were added, and

1. Janine Lockhart is a Librarian at Cape Peninsula University of Technology Libraries 
the updated version of the test was introduced in 2015. It is planned to do the item analysis on a regular basis to ensure the assessment instrument is continually updated and improved.

Further to the online multiple-choice assessment, it was important to measure how students applied their newlyacquired IL skills by completing a subject-specific essay assignment. Therefore, two assessment instruments were used: the multiple-choice test and an essay assignment.

The research questions of the study are the following:

- Does the current information literacy multiple-choice summative assessment show improvement in the IL knowledge of a student?

- $\quad$ Are students applying their information literacy skills in essay assignments after attending an IL course?

In the case of this research, it is hoped that the library would be able to demonstrate that it adds value to the academic programme and improves the IL skills of students.

\section{Review of the literature}

In higher education institutions, assessment of student learning is a focus area, therefore academic librarians need to provide evidence that "students acquire information literacy skills" (Belanger et al. 2015: 623). Academic libraries increasingly need to add value to their universities and their strategic goals. As stated by Berendt and Otero-Boisvert (2012: 78), "it is no longer sufficient, as it was in the past, to prepare monthly and annual reports that indicate gate counts, circulation statistics, and instruction sessions". They explained that, although that information will assist library managers in their planning, "they do not begin to paint a compelling picture of institutional impact and value". MacAyeal (2014:312) confirms this opinion and further indicates that traditional library assessment data does not demonstrate the impact that the library has on student learning or even faculty research.

Staley and Malenfant (2010: 57) indicated the importance of "futures thinking" for academic librarians and that "we [the academic library] must also know what will be valued in the future so that we can begin to take appropriate action now". Oakleaf (2010: 141) stated that "one way to work toward a positive vision of the future is to engage in the demonstration of library value, recognizing that the process is not one of proving value, but rather continuously increasing value".

Policy development is an important part of the process to successfully integrate IL into the curriculum at a university. As indicated by Grafstein (2002: 198), libraries have been teaching IL for many years with minimal success because it has mostly been initiated by librarians. She argued that these programmes could only succeed if they were to be developed and supported within an "explicit statement of philosophy from the highest levels of academic administration" and that IL should form "part of the educational mandate of the institution". In another study, Gullikson (2006: 588) indicated that faculty appreciates the value of IL skills and that they should be acquired by students in their first year. Race (2015) describes seven factors that underpin successful learning: wanting, needing, doing, making sense, feedback, verbalising and assessing. These factors need to be explored within each training intervention.

\subsection{Retention and skills transfer}

An important area to consider when discussing student learning is retention and skills transfer. Cook and Michael (2015: 35) define 'retention' as students remembering concepts and skills they are taught and 'transfer' as students "[taking] what they have learned and [applying] it to new, unrelated contexts". A question related to an IL intervention is to consider what would be a reasonable time for a student to become information literate, therefore retaining the knowledge and skills that were taught and being able to transfer those skills to various information challenges? Some studies (Selegean, Thomas \& Richman 1983: 477; Wang 2006: 80) indicated that pre-test/post-test assessment evaluation is limited to shortterm information retention, often not long-term retention. Werking (1980: 161) felt that students are often assessed immediately after receiving instruction and that short-term gains are likely not to be significant. That which is needed by the academic programme to support and improve information literacy skills transfer of students and ensure long-term retention should be considered.

CPUT Libraries offers the CIL mostly to first-year students, but the course is only the start to becoming fully information literate. It is very important that the academic programme continually tests and builds the information literacy skills of students. This sentiment is supported in a study by Dubicki (2013: 107) where she found that students' abilities in information literacy improved by year of education. In a study by Singh (2005: 302), faculty were asked how they would categorise the research skills of their students: only $1.7 \%$ rated their students' research skills as 'excellent'; $33,8 \%$ as poor. In one study, engineering professors indicated that their students' information literacy skills improved by their senior year (Saunders 2012: 227).

Research by Perkins (1986: 9) around 'thinking frames' and how human beings organise their thinking indicates that "since transfer cannot be relied upon to happen by itself, we must teach for transfer". According to Wong (2010: 118), Perkins explained a three-stage learning process which included "acquiring skills, making the skills automatic, and transferring the skills to other contexts of application". Applying skills that were taught in one subject to another is also an important issue to consider.

In a study by Lappalainen and Rosqvist (2014: 414), it was reported that the "first step required for transferring skills to a new situation is seeing a possible connection"; success also depends on the proficiency of skills the students have. Therefore, they asked teachers whether "their students appear to learn and carry skills well from one course to another", 
and if not, what they thought the possible problems and underlying reasons might be. This area needs further exploration and research.

\subsection{Assessing IL skills application}

Few studies have been done on faculty members' assessment of students' information literacy skills (Dubicki 2013: 98). In a study by Hoffman and LaBonte (2012: 76-77), it was found that IL proficiency levels in students can be shown by assessing writing assignments with a targeted rubric and that IL instruction has a positive correlation to the application of IL in written work. A rubric, as described by Stevens and Levi (2005: 3), divides an assignment into components and "provide[s] a detailed description of what constitutes acceptable or unacceptable levels of performance for each of those parts". It therefore communicates to students what is expected of them in the assignment. Another study (Daugherty \& Russo 2011: 324) reported that students who enrolled for an IL standalone course used the IL skills learned and applied those skills in other courses.

\subsection{Assessment methods}

Various assessment methods have been used by faculty and librarians, some more than others. According to Hurst and Leonard (2007) "citation analysis of student term papers has become a popular means of determining what sources students are utilizing to support their research". They also discussed the importance of assignments that are developed to take advantage of library resources together with information literacy teaching interventions. This practice would be beneficial to both the students and the faculty.

Walsh (2009: 21) reviewed the literature around information literacy assessment to see which assessment methods were used by librarians. He identified the following methods: analysis of bibliographies, essays, final grades, multiple choice, questionnaires, observation, portfolios, quizzes/tests, self-assessment and simulation. After multiple-choice, the analysis of bibliographies was the second-most popular method used. He found, however, that this method was subjective and time-consuming and the literature showed very little about its reliability and validity as an assessment method. Essays were another assessment method discussed in his study. Students could, for example, be asked to describe the information-seeking process they would use for a particular topic. This method will be explored as a further assessment instrument at CPUT. Observation as an assessment tool is mostly done in very small studies and not really suitable for mass assessment. This assessment tool would, however, provide valuable information about the informationseeking behaviour of students, although there is always a danger that people who are being observed might not act how they normally would. Simulations could assess how students would seek information and respond to a real problem, but this method does not seem to be sufficiently practical for regular use. Portfolio as an assessment tool is a time-consuming method and could not really be used for large number of students.

As indicated by Lindauer (2004: 122) "learning is complex and multidimensional and any serious attempt to assess learning must take a multi-methods approach". In the case of the CIL, two assessment methods were used: multiplechoice assessment and subject-specific essay writing assessment. Students also did various practical exercises during class time. The work from the previous week was used in the following week's class. For example, the development of a search strategy around the topic of the subject-specific essay assignment was used the following week for the searching of information using various tools, such as the catalogue and databases. It is important that what students are taught is real and of use to them - using an abstract topic to demonstrate IL concepts has not proven to be very effective. Cook and Michael (2015: 35) share five principles for structuring information literacy instruction, one of which is that the teaching should be done around a "concrete intellectual problem" and therefore teaching with the aid of a real assignment is critical. It will increase the motivation levels of the students and sessions will become more relevant to them.

\section{Methodology}

The researcher, who is the Chair of the Information Literacy Committee at CPUT as well as the training librarian, used a positivist approach and a quantitative method to measure the application of IL skills after completion of the Certificate in Information Literacy.

The sample of students consisted of two groups of first-year students from a single class in the Faculty of Business (now the Faculty of Business and Management Sciences) at the CPUT Cape Town campus who enrolled for the short course CIL during 2014. Altogether, the two groups numbered forty-two students. These students attended CIL classes during the third term of that year and were instructed by the researcher herself who covered the five modules over five weeks. Each module was taught over a ninety-minute class period. In the second term, before enrolling for the CIL, students completed an essay assignment (pre-essay) provided by their lecturer. The rubric for the essay gave a $40 \%$ weighting for information literacy, $20 \%$ for in-text referencing and $20 \%$ for the reference list. These marks were used for the pre-essay mark (result 1), as indicated in Figure 1.

The researcher gave the students an online multiple-choice pre-test before the teaching intervention. This is the pretest (result 2) as indicated in Figure 1. After the training intervention over five weeks, the students completed the online multiple-choice summative assessment, which is the post-test (result 3), as indicated in Figure 1. The pre-test was the same as the post-test, something of which students were not aware beforehand. The pre- and post-test consisted of fifty randomised questions that were selected after the item analysis tests were done (Lockhart 2014). The reason for using the same questions for both tests was because it would be "very difficult to make accurate comparisons between students" (Nunnally 1972:184) if they do not answer the same questions. At this time, the randomised selection of questions from a large bank of questions will continue to form part of the standard assessment for this short course. 
In an attempt to explore the validity of the online summative assessment further, the researcher wanted to measure how students applied their newly-acquired IL knowledge and skills through an actual essay assignment. The researcher worked alongside the lecturer of this group to ensure the development of a subject-specific essay assignment, the postessay (result 4). The assignment was used as the basis for teaching the CIL. The essay was developed in such a way as to ensure that IL skills were tested together with subject-knowledge. The researcher shared examples of IL rubrics found on Rubric Assessment of Information Literacy Skills (RAILS) with the lecturer who then developed the rubric for the essay assignment and allocated a 30\% weighting for IL. Rubrics are used to "guide analysis of student work" and are "descriptive scoring schemes" (Oakleaf 2008: 244). The lecturer assessed the assignment and shared the marks with the researcher.

Figure 1 Diagram showing the results used as part of the methodology

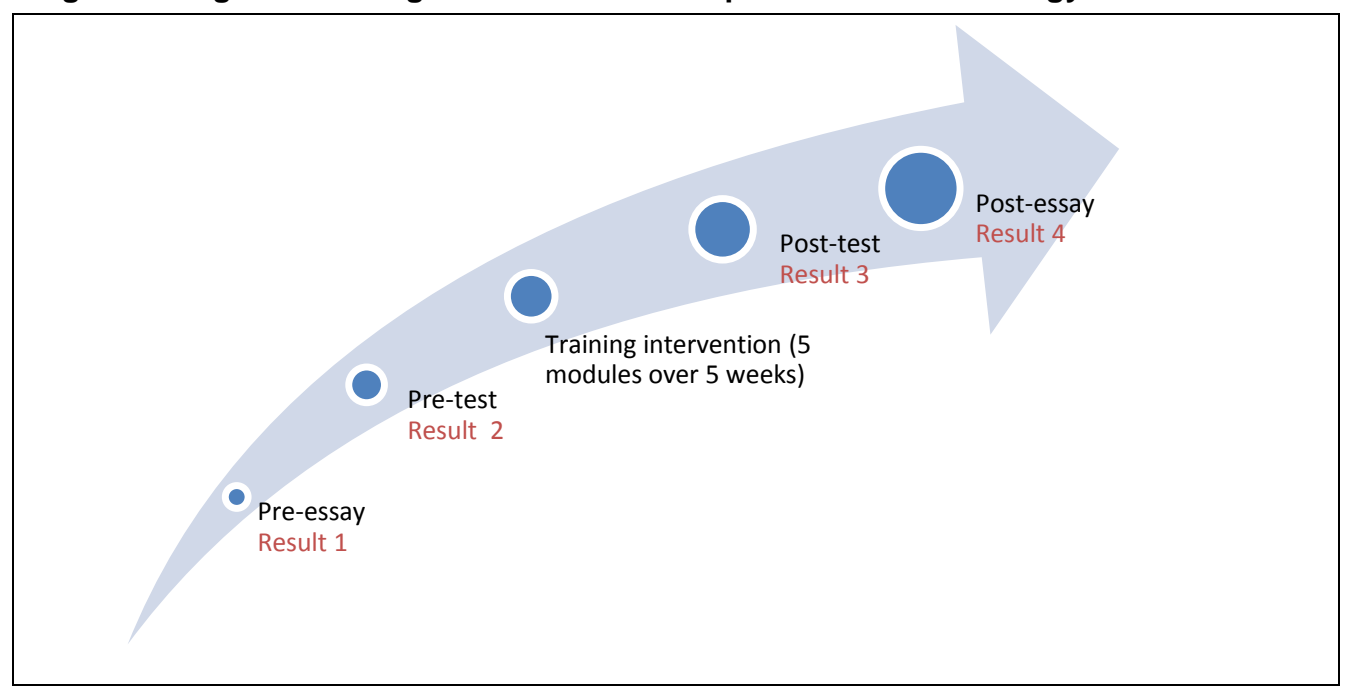

Out of the forty-two students, thirty-four students received results for three of the assessments (pre-test (result 2), post-test (result 3), post-essay (result 4)). Out of this group, twenty-five students received a result for the pre-essay (result 1). Therefore, not all forty-two students completed or submitted all four assessments. The data was analysed as follows.

The descriptive statistics were determined for all four results (number, minimum, maximum, mean and standard deviation). Paired sample t-tests were then done between:

- Pair 1: post-test and pre-test (result 3 and result 2)

- Pair 2: post-essay and pre-essay (result 4 and result 1)

A paired sample t-test is to determine "whether the means of two samples that come from the same or similar cases are significantly different from each other" (Cramer \& Howitt 2004: 168). A Wilcoxon Signed Rank test was done between the post-test (result 3) and the post-essay (result 4). According to Kremelberg (2011), "this test is the non-parametric equivalent of the paired t-test"; it does not assume distribution. The test is therefore to see how many students performed better in the post-essay than the multiple-choice post-test.

\section{Results and discussion}

The descriptive statistics for the four results (pre-essay, pre-test, post-test and post-essay) are indicated in Table 1.

Table 1 Descriptive statistics

\begin{tabular}{lccccc}
\hline & N & Minimum & Maximum & Mean & Std. Deviation \\
\hline Pre-essay (result 1) & 25 & 30 & 88 & 62.24 & 15.07 \\
Pre-test (result 2) & 34 & 26 & 78 & 57.88 & 10.55 \\
Post-test (result 3) & 34 & 58 & 88 & 74.41 & 8.03 \\
Post-essay (result 4) & 34 & 40 & 88 & 63.97 & 12.61 \\
\hline
\end{tabular}

Table 2 indicates the analysis of the paired sample tests. The differences are calculated for all the students and then the average difference is determined.

Pair 1 (pre-test and post-test) showed an increase of $16 \%$ on average. The p-value was much less than .001 and therefore there is a statistically significant increase from the pre-test to the post-test. According to (Field 2009: 53), if the p-value is less than 0.05 , then the alternative hypothesis is accepted. It is therefore confirmed that the students did much better in the post-test than in the pre-test. 
Pair 2 (pre-essay and post-essay) showed a 3\% increase from the pre-essay to the post-essay. Even though it is a very small increase, the $p$-value was less than .05 and therefore a statistically significant increase. This confirms that the students showed an improvement from the pre-essay to the post-essay in applying their IL knowledge and skills that they learnt during the CIL classes. This, however, poses the question about skills transfer and what would be a reasonable expectation thereof.

Table 2 Paired samples test

\begin{tabular}{|c|c|c|c|c|c|c|c|c|c|}
\hline & & \multicolumn{5}{|c|}{ Paired Differences } & \multirow{3}{*}{$\mathbf{t}$} & \multirow{3}{*}{ df } & \multirow{3}{*}{$\begin{array}{c}\text { p-value } \\
\text { (2-tailed) }\end{array}$} \\
\hline & & \multirow{2}{*}{$\begin{array}{c}\text { Mean } \\
\text { Difference }\end{array}$} & \multirow{2}{*}{$\begin{array}{c}\text { Std. } \\
\text { Deviation }\end{array}$} & \multirow{2}{*}{$\begin{array}{l}\text { Std. Error } \\
\text { Mean }\end{array}$} & \multicolumn{2}{|c|}{$\begin{array}{l}95 \% \text { Confidence } \\
\text { Interval of the } \\
\text { Difference }\end{array}$} & & & \\
\hline & & & & & Lower & Upper & & & \\
\hline Pair 1 & $\begin{array}{l}\text { Post-test - Pre-test } \\
\text { (result } 3 \text { - result 2) }\end{array}$ & 16.53 & 10.11 & 1.73 & 13.002 & 20.06 & 9.54 & 33 & 0.000 \\
\hline Pair 2 & $\begin{array}{l}\text { Post-essay - Pre-essay } \\
\text { (result } 4 \text { - result } 1 \text { ) }\end{array}$ & 3.16 & 6.08 & 1.22 & 0.65 & 5.67 & 2.60 & 24 & 0.016 \\
\hline
\end{tabular}

In other studies (Dubicki 2013; Saunders 2012), it was shown that students' IL skills mostly improved by year of education and were much-improved by their senior year. The students who formed part of the CPUT study were in their first year and therefore a small improvement could possibly have been expected. Becoming information literate is a process and skills transfer takes time; it will not happen immediately. It is also important to note that skills transfer will continue only if the academic programme continues to test IL skills. If someone practises a skill repeatedly, he/she should get better at it. If there is no continuous academic assessment for IL after an IL training intervention such as the CIL, students will probably lose the skills they were taught and not necessarily apply them in future essays or across subjects, therefore showing short-term retention only.

Figure 2 Wilcoxon Signed Rank Test

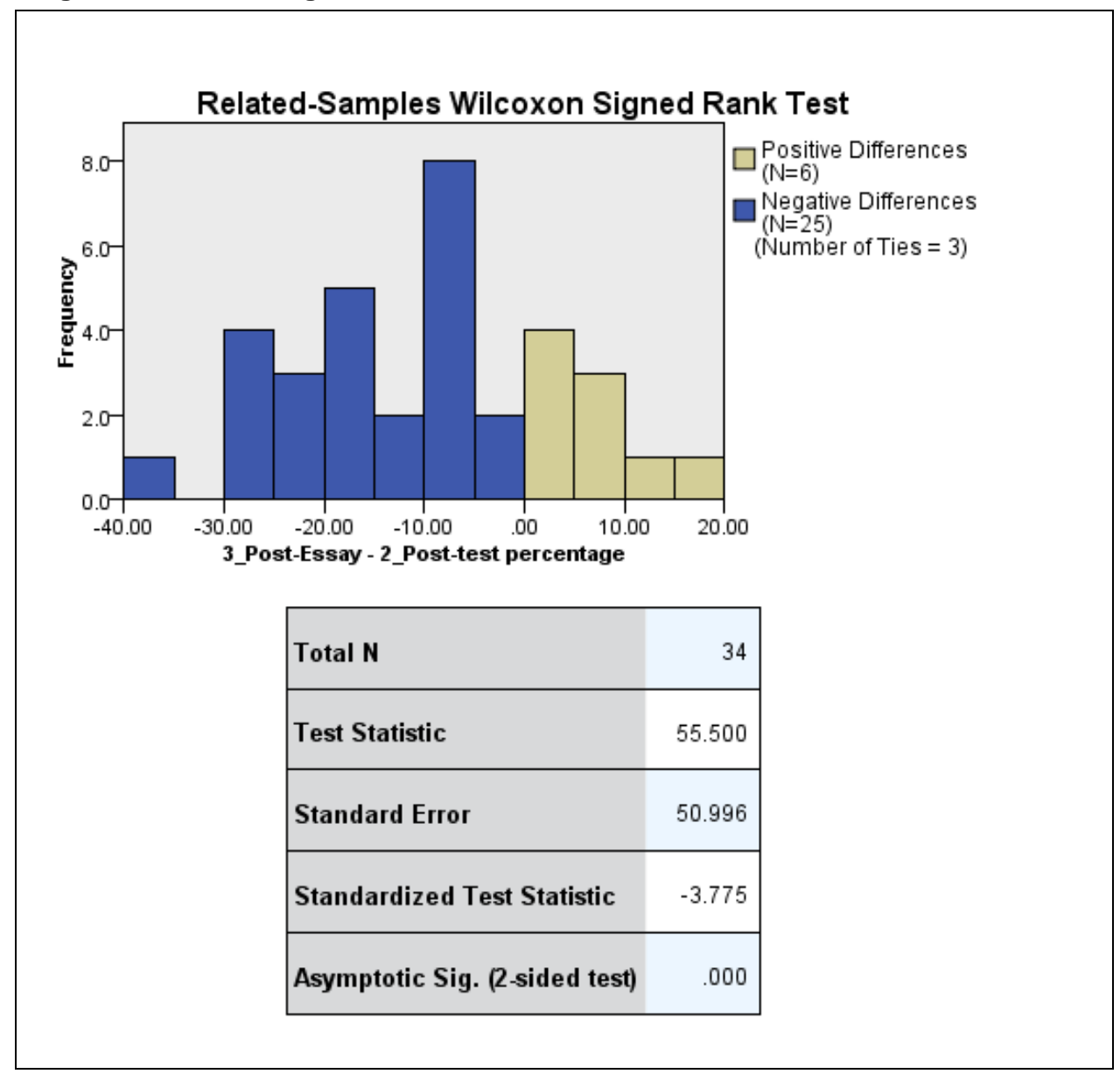

To ensure that continuous assessment takes place and that IL is embedded within the full curriculum of an academic programme, a departmental approach should be considered. A departmental approach would be where the entire faculty 
involved in an academic programme (all subjects and levels of study) work together with the librarian to ensure that all essay-writing assignments are developed to test IL skills and that rubrics include heavy weightings for IL. The librarians could play an important role in beginning this conversation within an academic department.

The Wilcoxon Signed Rank test, as seen in Figure 2, compared the multiple-choice post-test (result 3) and the postessay (result 4) to see how many students performed better in the post-essay than the post-test. It is important to note that two different assessment instruments are being compared here: a multiple-choice online assessment and a subjectspecific essay. Six of the students fared better in the post-essay, twenty-five students fared better in the post-test, and three students achieved the same for both. There was a statistically significant difference in the results that indicated that students did overall much better in the multiple-choice post-test (result 3) than in the post-essay (result 4). These results confirm that applying IL skills in an essay assignment is more challenging than answering multiple-choice questions, which mostly test knowledge. It is possibly better to use a multi-method assessment approach when assessing IL, therefore not relying only on a multiple-choice online assessment. This approach could be taken in a partnership between the lecturer and the librarian.

Based on the results, both research questions for this study have been found to have a positive outcome: the current information literacy multiple-choice summative assessment showed improvement in the IL knowledge of a student and students are applying their information literacy skills in essay assignments after attending an IL course. This study therefore confirmed that students applied their information literacy skills in their essay assignments after attending an IL short course.

\section{Conclusion}

It is clear that academic libraries need to demonstrate their value and link to the strategic plans of the university. There has to be explicit buy-in from top management for any process to be successfully implemented. This study established that offering a short course in IL, such as the CIL, improved the information literacy skills of students. It showed improvement in the knowledge gained by students in the multiple-choice assessment as well as the application of IL skills in their essay assignments. It also highlighted that skills transfer is a process which takes time. Librarians should teach for long-term transfer by working closely with faculty and ensuring that assessment of IL skills continues for the full duration of the academic programme; a departmental approach to IL is needed. Academic libraries should be partners in the academic process, which includes assessment methods and measuring the application of IL skills.

\section{Acknowledgements}

The author would like to acknowledge Ms A. Reiners, lecturer in the Faculty of Business and Management Sciences at CPUT; librarians Ms Z. Davids and Ms P. Mothopeng for supporting this study; and Ms C. Uys, statistician at CPUT.

\section{References}

Belanger, J., Zou, N., Mills, J., Holmes, C. and Oakleaf, M. 2015. Project RAILS: lessons learned about rubric assessment of information literacy skills. Libraries and the academy, 15(4): 623-644.

Berendt, L. and Otero-Boisvert, M. 2012. Future-proofing the academic librarian. In Defending professionalism: a resource for librarians, information specialists, knowledge managers, and archivists. B. Crowley, Ed. Santa Barbara: CA: Libraries Unlimited: 75-90.

Cape Peninsula University of Technology. 2015. Extended curriculum. [Online]. http://www.cput.ac.za/services/fundani/extended (13 May 2015).

Cook, D.B. and Michael, K. 2015. How do our students learn? An outline of a cognitive psychological model for information literacy instruction. Reference, 55(1): 34-41.

Cramer, D. and Howitt, D. 2004. $t$ test for related samples. The SAGE dictionary of statistics. [Online]. http://srmo.sagepub.com/view/the-sage-dictionary-of-statistics/SAGE.xml.

Daugherty, A.L. and Russo, M.F. 2011. An assessment of the lasting effects of a stand-alone information literacy course: the students' perspective. The Journal of Academic Librarianship, 37(4): 319-326. [Online]. http://www.sciencedirect.com/science/article/pii/S0099133311000747 (16 May 2014).

Dubicki, E. 2013. Faculty perceptions of students' information literacy skills competencies. Journal of Information Literacy, $7(2): 97-125$.

Field, A. 2009. Discovering statistics using SPSS: (and sex and drugs and rock $n$ roll). London: Sage.

Grafstein, A. 2002. A discipline-based approach to information literacy. The Journal of Academic Librarianship, 28(4): 197-204. [Online]. http://linkinghub.elsevier.com/retrieve/pii/S0099133302002835.

Gullikson, S. 2006. Faculty perceptions of ACRL's information literacy competency standards for higher education. The Journal of Academic Librarianship, 32(6): 583-592. [Online]. http://www.sciencedirect.com/science/article/pii/S0099133306001054 (16 May 2014).

Hoffman, D. and LaBonte, K. 2012. Meeting information literacy outcomes: partnering with faculty to create effective information literacy assessment. Journal of information Literacy, 6(2): 70-85.

Hurst, S. and Leonard, J. 2007. Garbage in, garbage out: the effect of library instruction on the quality of students' term papers. Electronic Journal of Academic and Special Librarianship, 8(1).

Kremelberg, D. 2011. Practical statistics: a quick and easy guide to IBM and SPSS statistics, STATA, and other statistical software. Thousand Oaks: SAGE Publishers. 
Lappalainen, J. and Rosqvist, J. 2014. Exploring hurdles to transfer: student experiences of applying knowledge across disciplines. International Journal of Mathematical Education in Science and Technology, 46(3): 404-419. [Online]. http://www.tandfonline.com/doi/abs/10.1080/0020739X.2014.982729.

Lindauer, B.G. 2004. The three arenas of information literacy assessment. Reference \& User Services Quarterly, 44(2): 122-129.

Lockhart, J. 2015. Increasing library value for users by registering a short course in information literacy. Proceedings of the IATUL Conferences. 5 - 9 July 2015. German National Library of Science and Technology, Hannover, Germany: Purdue. Paper 7. [Online]. http://docs.lib.purdue.edu/cgi/viewcontent.cgi?article=2092\&context=iatul.

Lockhart, J. 2014. Using item analysis to evaluate the validity and reliability of an existing online information literacy skills assessment instrument. South African Journal of Libraries and Information Science, 80(2): 36-45.

MacAyeal, G. 2014. A culture of assessment: five mindsets. College \& Research Libraries: 311-312.

Nunnally, J. 1972. Educational measurement and evaluation. 2nd ed. New York: McGraw-Hill.

Oakleaf, M. 2008. Dangers and opportunities: a conceptual map of information literacy assessment approaches. Libraries and the Academy, 8(3): 233-253.

Oakleaf, M. 2010. Value of academic libraries: a comprehensive research review and report. Chicago: Association of College and Research Libraries.

Perkins, D.N. 1986. Thinking frames. Educational leadership, 43(8): 4-10.

Race, P. 2015. The lecturer's toolkit: a practical guide to assessment, learning and teaching. 4th ed. New York: Routledge.

Saunders, L. 2012. Faculty perspectives on information literacy as a student learning outcome. The Journal Of Academic Librarianship, 38(4): 226-236.

Selegean, J., Thomas, M. and Richman, M. 1983. Long-range effectiveness of library use instruction. College \& Research Libraries: 476-480. [Online]. http://crl.acrl.org/content/44/6/476.full.pdf.

Singh, A.B. 2005. A report on faculty perceptions of students' information literacy competencies in journalism and mass communication programs: the ACEJMC survey. College \& Research Libraries, 66(4): 294-310.

Staley, D.J. and Malenfant, K.J. 2010. Futures thinking for academic librarians: higher education in 2025. Information Services \& Use, 30: 57-90.

Stevens, D. and Levi, A. 2005. Introduction to rubrics. Sterling: Stylus Publishing.

Walsh, A. 2009. Information literacy assessment: where do we start? Journal of Librarianship and Information Science, 41(1): 19-28.

Wang, R. 2006. The lasting impact of a library credit course. portal: Libraries and the Academy, 6(1): 79-92.

Werking, R.H. 1980. Evaluating bibliographic education : a review and critique. Library Trends, 29(1): 153-173.

Wong, G.K.W. 2010. Facilitating students' intellectual growth in information literacy teaching. Reference \& User Services Quarterly, 50(2): 114-118. 